\title{
CERAMIC MASONRY UNITS INTENDED FOR THE MASONRY RESISTANT TO HIGH HUMIDITY
}

\author{
KERAMIČNI GRADBENI ELEMENTI, NAMENJENI ZA ZGRADBE, \\ ODPORNE PROTI VISOKI VLAGI
}

\author{
Jiř́ Zach, Vítězslav Novák, Jitka Hroudová, Martin Sedlmajer \\ Brno University of Technology, Faculty of Civil Engineering, Veveří 331/95, 60200 Brno, Czech Republic \\ zach.j@fce.vutbr.cz,novak.v@fce.vutbr.cz, hroudova.j@fce.vutbr.cz, sedlmajer.m@fce.vutbr.cz \\ Prejem rokopisa - received: 2014-08-01; sprejem za objavo - accepted for publication: 2014-10-14
}

doi:10.17222/mit.2014.170

\begin{abstract}
The Faculty of Civil Engineering has been developing modern masonry blocks for several years. The aim is to develop masonry units that provide a good thermal insulation, mechanical and acoustic properties and a reduction in the energy consumption required for their production. Given the ever increasing frequency of natural disasters, which also affect landlocked countries, a part of this research also focuses on the development of ceramic blocks resistant to high humidity. High humidity is one of the most harmful effects occurring in a building construction. It causes an overall deterioration of the building construction and can lead to its degradation. Ceramic-brick constructions are already under stress due to a high humidity during the building period and also afterwards during their use. However, natural disasters such as floods, which have often occurred in the Czech Republic in recent years, cause the destruction of building constructions and their subsequent demolition. The paper deals with the possibility of a preventive use of hydrophobic ceramic masonry units intended for masonry plinths. This hydrophobisation serves as the prevention in the cases, in which the conventional waterproofing fails and also in the case of an extremely high humidity.

Keywords: ceramic masonry blocks, high humidity, hydrophobic, waterproofing, capillary absorption
\end{abstract}

Fakulteta za gradbeništvo že več let razvija moderne gradbene elemente. Namen je razviti moderno gradbeno enoto, ki bo imela dobro toplotno izolacijo, mehanske in akustične lastnosti ter zmanjšano porabo energije za njeno proizvodnjo. Zaradi vedno večje pogostosti naravnih katastrof, ki vplivajo tudi na otoške države, je del razvoja usmerjen tudi v razvoj keramičnih opek, odpornih proti visoki vlagi. Ta je med najbolj škodljivimi vplivi na gradbeno konstrukcijo. Povzroča splošno poslabšanje zgradbe in lahko povzroči celo njen razpad. Konstrukcije iz keramičnih opek so izpostavljene veliki vlagi že pri gradnji, kot tudi kasneje pri uporabi. Pri naravnih nesrečah, kot so poplave, ki so bile zadnja leta pogoste v Češki Republiki, so bile vzrok za uničenje gradbenih konstrukcij in posledično rušenje le-teh. Članek obravnava možnost preventivne uporabe hidrofobne keramične opeke za podlago zgradbe. Ta hidrofobizacija se uporablja kot zaščita v primeru, kjer navadna hidroizolacija odpove, in tudi $\mathrm{v}$ primerih ekstremno visoke vlažnosti.

Ključne besede: keramični gradbeni elementi, visoka vlažnost, hidrofoben, hidroizolacija, kapilarna absorpcija

\section{INTRODUCTION}

Two waterproofing principles can be applied to protect a building construction from the negative effects of water and moisture: ${ }^{1,2}$

The indirect waterproofing principle - following this principle, we minimise/reduce the moisture stress on a construction, e.g., by placing the building in an optimum environment, using the drainage of the adjacent building, increasing the surface temperature of the construction, etc.

The direct waterproofing principle - following this principle, we prevent water and moisture from penetrating into the structure. This is achieved by means of waterproof (or moisture-proof) materials, e.g., continuous-sheet waterproofing, waterproof concrete, injections, surface penetration and impregnation, surface hydrophobisation, ${ }^{3-5}$ etc. It is also possible to prevent water or moisture penetration using active methods for reducing the moisture stress on a construction, e.g., electokinetic methods.
Masonry constructions, especially their lower parts, are under stress from increased moisture. Increased moisture has an effect both during the construction and during the use of a building. Building constructions are protected from increased moisture by horizontal, continuous, waterproof sheets and by the surface finish on the outside. $^{6}$

In the case of increased moisture during the construction, the moisture mainly penetrates into the structure prior to the roof construction and surface finishing. A moisture increase during the construction does not necessarily mean that it has a decisive influence on the building. However, the building must not be sealed or used immediately after the finishing if it is completed in autumn or winter. If we fail to do so, a deterioration of the thermal properties often occurs due to the moisture in the lower parts of the building, often leading to hygrothermal failures such as damp areas and moulds.

The stress caused by increased moisture during the use of a building can have a number of causes. It may be a failure of the horizontal/vertical waterproofing as a 
result of damage or a faulty application. Furthermore, waterproofing can be damaged during additional building operations, such as vents or wall repairs, etc. Waterproofing is also ineffective if the masonry reaches over the foundation plate, into the exterior. In the case of increased moisture during the use of the building, the problem is considerably more serious and the degree of masonry degradation is determined by the moisture stress.

To prevent hygric defects, hydrophobised masonry units can be used in the lower part of a masonry construction. This paper deals with the possibilities of additional hydrophobisation of ceramic bricks using chemical hydrophobic agents available in the EU market.

\section{SPECIMENS}

The specimens for testing the hydrophobisation of ceramic bricks were intended for the plinth masonry. They were wall bricks with a thickness of $250 \mathrm{~mm}$. The bricks were chosen because of their low mass, small dimensions and the water absorption equal to that of the bricks used in thicker walls.

\section{HYDROPHOBIC AGENTS}

A total of five specimens from different producers and of different chemical compositions were chosen for the laboratory experiments. All the tested hydrophobic agents were silicon-based. They were organosilicate compounds exhibiting a high thermal resistance between $-50{ }^{\circ} \mathrm{C}$ and $200{ }^{\circ} \mathrm{C}$, the resistance to sudden temperature change, weather, sunlight and a high chemical resistance. A hydrophobic film was formed thanks to the intermolecular condensation of low-molecular-weight methylsiloxanes through the effect of atmospheric carbon dioxide. The main condition of the hydrophobising effect was the orientation of silicone molecules towards the surface of the masonry. There was a high amount of short-chain hydrocarbon residue, e.g., methyl, ethyl group $\left(\mathrm{CH}_{3-}\right.$, $\mathrm{C}_{2} \mathrm{H}_{5-}$ ) (Figure 1). This weak, often macromolecular, layer increases the contact angle to such an extent that the capillary elevation is reduced to zero or even that a capillary depression occurs. Thanks to this principle, the water-vapour and gas permeability of the building material is retained. These hydrophobic agents cannot be used in the cases where water under pressure acts upon the structure. ${ }^{7}$

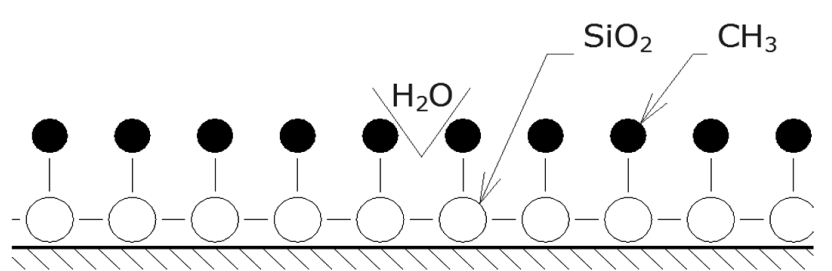

Figure 1: Orientation of silicone molecules ${ }^{7}$ Slika 1: Orientacija silikonskih molekul ${ }^{7}$
Some the most frequently used waterproofing preparations are silicone resin solutions formed in organic solvents, most often in white spirit or benzine. The resin content usually ranges from $3 \%$ to $8 \%$. These are single-component solutions, mostly colourless or with a slight yellow hue and transparent; the hydrophobic effect occurs immediately after the solvent evaporates. These preparations cannot be used on wet surfaces; they can be used for hydrophobising previously hydrophobised materials. The presence of the solvent is disadvantageous in terms of fire, ecological and possible health hazard.

The other silicone hydrophobic agents are low-molecular-weight compounds - oligomers, which, due to air humidity, spontaneously polymerise upon application, producing the desired polymer. They are usually singlecompound, translucent and colourless. Their advantage over the high-molecular-weight resins lies in their ability to chemically bond with the surfaces of quartz grains (if present) of the material being treated, thus increasing the abrasion resistance. They are sometimes supplied as a concentrate and the preparation is performed by mixing it with an appropriate solvent. Another advantage is their better ability to penetrate into a porous material.

Silicone microemulsions represent a special group. They are again silicone compounds with a relatively low molecular weight which, thanks to their molecular structure, are able to produce an emulsion with very small particles after being mixed with water. A slow reaction with water then produces the desired hydrophobic polymer. Their advantage lies in the possibility of mixing with water which facilitates the avoidance of organic solvents and a good penetration capability.

Methylsilanolates (methylsiliconates) - sodium or potassium - also belong to silicone hydrophobic agents. These substances are hydrophobising varieties of soluble glass. Similarly to soluble glass, when in contact with carbon dioxide, they are transformed into a modified gel of silicic acid that is hydrophobic in this case. Unfortunately, this chemical reaction also produces a hydroxide of the respective metal (sodium or potassium), later transformed into a carbonate. Thus, undesirable watersoluble efflorescent salts enter the structure of the material being treated. Their presence represents the risk of the formation of white efflorescence and even the degradation of the treated material due to the crystallisation pressure. The advantages of siliconates are their good water solubility (i.e., the possibility of application onto wet surfaces) and substantially lower prices in com-

Table 1: Used hydrophobic agents

Tabela 1: Uporabljena hidrofobna sredstva

\begin{tabular}{|c|l|}
\hline No. & \multicolumn{1}{|c|}{ Description } \\
\hline 1 & Silane-siloxane microemulsion cream \\
\hline 2 & Potassium methylsilanolate preparation \\
\hline 3 & Hydrophobised siliconate solution \\
\hline 4 & Solvent-free siloxane emulsion \\
\hline 5 & Siloxane base with aromatic-free organic solvents \\
\hline
\end{tabular}


parison with the other silicone preparations. The resulting gel is non-soluble and thus effectively unremovable. Silanolates are recommended for the protection of historical buildings thanks to their good solubility and low price ${ }^{8,9}$.

Table 1 contains an overview of the tested hydrophobic agents.

The soaking in hydrophobising solutions was always performed for (10, 20 and 30) s; only non-water-soluble preparations were applied by spraying them in a given amount. Next, the individual specimens were stored after the application of the hydrophobic agent in the laboratory environment for a week in order for the excess moisture to evaporate. The following tests were performed with the specimens thus prepared.

The bricks were put in a plastic box onto a wooden grid. Subsequently, they were flooded with water at a temperature of $(20 \pm 2){ }^{\circ} \mathrm{C}$, always up to $50 \mathrm{~mm}$ of the height of the bricks. The bricks were weighed at regular intervals: after (1, 2, 3, 6, 24, 48, 72 and 96) h.

\section{RESULTS}

Hydrophobic preparations Nos. 1-4 were applied by soaking for (10, 20 and 30) s. Hydrophobic agent No. 5 was applied by being sprayed in the amount of approximately $250 \mathrm{~g}$ per brick. The measurement was also performed on the non-hydrophobised bricks. The testing was always carried out on two specimen bricks with a given hydrophobic-agent concentration and an immersion time. Hydrophobic agents Nos. 1, 2 and 4 were always prepared in two concentrations. The overview of the tested concentrations is summarized below:

- solution No. 1 was tested at concentrations of $1: 20$ and $1: 30$,

- solution No. 2 was tested at concentrations of $1: 10$ and $1: 25$,

- solution No. 3 was tested at a concentration of $1: 2$,

- solution No. 4 was tested at concentrations of $1: 15$ and $1: 30$.

The quantity being measured was the brick mass at the end of each interval $(1,2,3,6,24,48,72$ and 96) $\mathrm{h}$. The amount of the absorbed water was calculated from the ratio of the measured mass to the brick surface area. Its capillary absorption was determined with the following formula:

$$
A_{\mathrm{w}}=\frac{m_{\mathrm{w}}}{A}
$$

$A_{\mathrm{w}}$ - capillary absorption in time $\left(\mathrm{kg} \mathrm{m}^{-2}\right)$

$m_{\mathrm{W}}-$ mass of the brick soaked with water $(\mathrm{kg})$

$A$ - area of the brick $\left(\mathrm{m}^{2}\right)$

The values of the capillary absorption can be compared with each other despite the different methods of the application of the hydrophobic agents which is the validity of their efficiency. The results of the individual measurements are in Table 2:
Table 2: Overview of the obtained absorption values of the specimens Tabela 2: Pregled dobljenih vrednosti absorpcije vzorcev

\begin{tabular}{|c|c|c|c|c|c|c|}
\hline \multirow{2}{*}{$\begin{array}{l}\text { Hydro- } \\
\text { phobic } \\
\text { agent } \\
\text { number }\end{array}$} & \multirow[t]{2}{*}{$\begin{array}{l}\text { Con- } \\
\text { centra- } \\
\text { tion }\end{array}$} & \multirow[t]{2}{*}{$\begin{array}{l}\text { Dipping } \\
\text { time (s) }\end{array}$} & \multicolumn{2}{|c|}{$\begin{array}{l}\text { Absorption } \\
(\%)\end{array}$} & \multicolumn{2}{|c|}{$\begin{array}{l}\text { Capillary } \\
\text { absorption } \\
\left(\mathrm{kg} \mathrm{m}^{-2}\right)\end{array}$} \\
\hline & & & $24 \mathrm{~h}$ & $96 \mathrm{~h}$ & $24 \mathrm{~h}$ & $96 \mathrm{~h}$ \\
\hline \multirow{6}{*}{1} & \multirow{3}{*}{$1: 30$} & 10 & 0.42 & 1.60 & 0.79 & 3.04 \\
\hline & & 20 & 0.41 & 1.39 & 0.77 & 2.64 \\
\hline & & 30 & 0.24 & 0.93 & 0.45 & 1.77 \\
\hline & \multirow{3}{*}{$1: 20$} & 10 & 0.35 & 0.76 & 0.65 & 1.44 \\
\hline & & 20 & 0.36 & 0.72 & 0.63 & 1.36 \\
\hline & & 30 & 0.38 & 0.67 & 0.60 & 1.27 \\
\hline \multirow{6}{*}{2} & \multirow{3}{*}{$1: 25$} & 10 & 16.38 & 22.05 & 32.98 & 42.31 \\
\hline & & 20 & 15.52 & 21.51 & 29.78 & 40.56 \\
\hline & & 30 & 11.08 & 20.14 & 20.65 & 40.07 \\
\hline & \multirow{3}{*}{$1: 10$} & 10 & 10.27 & 19.77 & 20.97 & 40.03 \\
\hline & & 20 & 8.47 & 19.61 & 17.26 & 38.19 \\
\hline & & 30 & 6.54 & 17.65 & 12.63 & 35.98 \\
\hline \multirow{3}{*}{3} & \multirow{3}{*}{$1: 2$} & 10 & 1.36 & 2.91 & 2.50 & 5.33 \\
\hline & & 20 & 1.26 & 2.15 & 2.44 & 4.16 \\
\hline & & 30 & 1.21 & 2.11 & 2.13 & 3.89 \\
\hline \multirow{6}{*}{4} & \multirow{3}{*}{$1: 30$} & 10 & 8.58 & 16.21 & 15.69 & 29.51 \\
\hline & & 20 & 7.51 & 15.42 & 11.74 & 28.19 \\
\hline & & 30 & 6.25 & 15.11 & 10.85 & 26.52 \\
\hline & \multirow{3}{*}{$1: 15$} & 10 & 6.01 & 12.65 & 12.35 & 24.64 \\
\hline & & 20 & 6.34 & 12.35 & 11.32 & 23.25 \\
\hline & & 30 & 5.52 & 11.01 & 6.28 & 19.97 \\
\hline 5 & - & - & 9.42 & 17.26 & 18.39 & 33.70 \\
\hline $\begin{array}{l}\text { Refe- } \\
\text { rence }\end{array}$ & - & - & 25.70 & 27.22 & 47.65 & 50.47 \\
\hline
\end{tabular}

The table shows that the effectiveness of individual hydrophobic agents varies significantly. The effectiveness of the hydrophobic agents is influenced by the concentration and the soaking time. The following chart compares the effectiveness values for the hydrophobic agents after $96 \mathrm{~h}$ of soaking in water by means of capillary absorption (Figure 2).

The values show that the most effective hydrophobisation was achieved by applying hydrophobic agent No. 1 , specifically at a concentration of $1: 20$. The following chart on Figure 3 shows the progression of the capillary

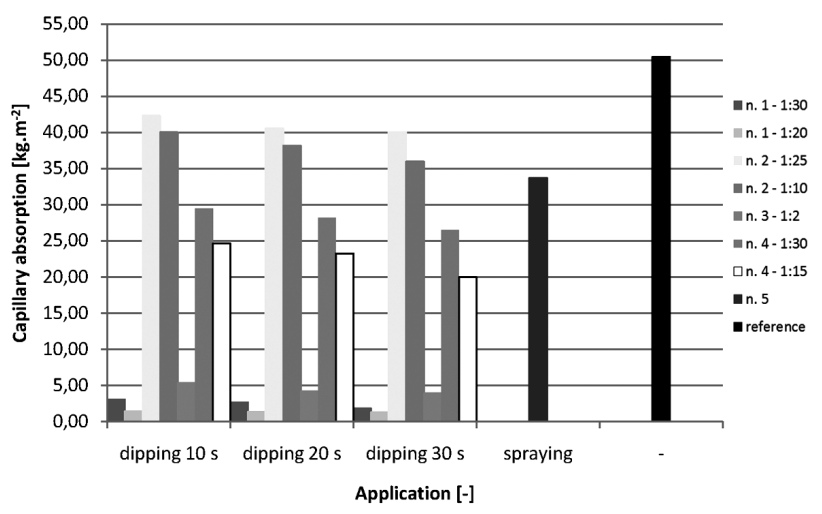

Figure 2: Capillary absorption of individual hydrophobic agents Slika 2: Kapilarna absorpcija pri uporabi posameznih hidrofobnih snovi 
J. ZACH et al.: CERAMIC MASONRY UNITS INTENDED FOR THE MASONRY RESISTANT ...

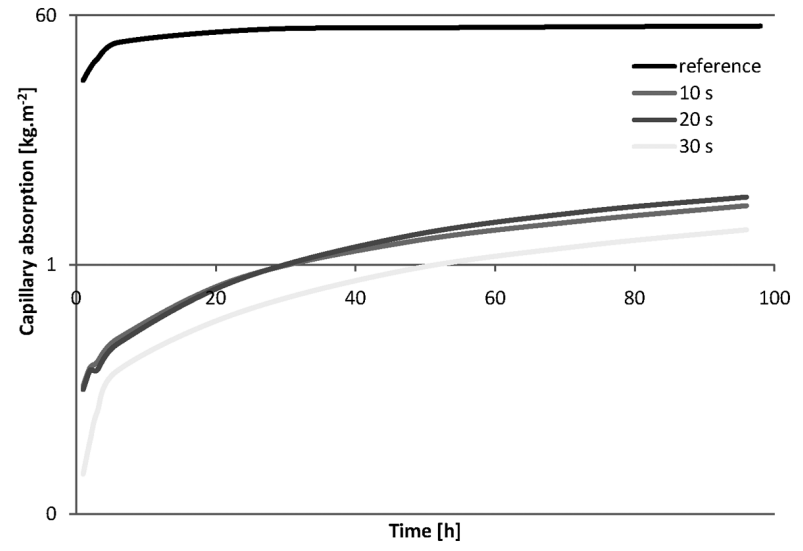

Figure 3: Process of capillary absorption over time for hydrophobic agent No. 1 ( $1: 20)$

Slika 3: Potek kapilarne absorpcije v odvisnosti od časa pri hidrofobni snovi št. $1(1: 20)$

absorption over time of this hydrophobic agent applied by soaking for $(10,20$ and 30$) \mathrm{s}$, in comparison with the reference capillary absorption.

\section{CONCLUSION}

Table 2 lists all the experimentally obtained values, which show, when compared to the reference values, that the capillary absorption was reduced in all the instances by applying the tested hydrophobic agents. The effectiveness of the hydrophobic agents is influenced by the type of the preparation, its concentration and the time of the treatment with the agent.

The best results were reached using hydrophobic agent No. 1, i.e., the agent based on the silane-siloxane microemulsion cream with a concentration a $1: 20$. With this hydrophobic agent, as with as all the others, an increasing soaking time caused an increase in the effectiveness of the preparation at a reduced capillary absorption.

It is necessary to note that during a long-term exposure to moisture, capillarity is always at work. These tested hydrophobic agents cannot be considered as complete substitutes for sheet waterproofing; however, they can be used for masonry protection during construction. Also, in the case of an occasional moisture stress on the lower part of the masonry (spraying precipitation moisture), hydrophobic agents provide a sufficient protection.

\section{Acknowledgements}

This paper was elaborated with the financial support of the Technology Agency of the Czech Republic within the project under ref. n. TA04020920 and the project no. L01408 "ADMAS Up - Advanced Materials, Structures and Technologies".

\section{REFERENCES}

${ }^{1}$ Czech standard CSN P 73 0600, Waterproofing of buildings - Basic provisions, 2000

${ }^{2}$ Czech standard CSN P 73 0610, Waterproofing of buildings - The rehabilitation of damp masonry and additional protection of buildings against ground moisture and against atmospheric water - Basic provision, 2000

${ }^{3}$ D. Beben, Z. Manko, Influence of selected hydrophobic agents on some properties of autoclaving cellular concrete (ACC), Construction and Building Materials, 25 (2011), 282-287, doi:10.1016/ j.conbuildmat.2010.06.028

${ }^{4}$ M. Medeiros, P. Helene, Efficacy of surface hydrophobic agents in reducing water and chloride ion penetration in concrete, Mater. Struct., 41 (2008), 59-71, doi:10.1617/S11527-006-9218-5

${ }^{5}$ L. Wolff, M. Raupach, Hydrophobieren von Stahlbetonoberflächen, Betonwerk und Fertigteil-Technik, 69 (2003) 10, 12-21

${ }^{6}$ Czech standard CSN P 73 0606, Waterproofing of buildings - Continuous sheet water proofing - Basic provisions, 2000

${ }^{7}$ R. Drochytka, Plastic substances, Study support, VUT Brno, Brno, 2007

${ }^{8}$ J. de Vries, R. B. Polder, Hydrophobic Treatment of Concrete, Construction and Building Materials, 11 (1997) 4, 259-265, doi:10.1016/ S0950-0618(97)00046-9

${ }^{9}$ P. Kotlík, Stavební materiály historických objektů, 1. vydání, Praha 1999 